\title{
The Estimation of GC Repeats in Promoter P1 of IGF-1 Gene and Their Influence on IGF-1 Plasma Levels in Stable Angina Patients
}

\author{
Pawel Burchardt - Witold Nowak · Jakub Zurawski • \\ Anna Gozdzicka-Jozefiak • Tomasz Siminiak
}

Published online: 25 September 2010

(c) The Author(s) 2010. This article is published with open access at Springerlink.com

\begin{abstract}
Increased plasma levels of insulin-like growth factor 1 (IGF-1) are observed in advanced arteriosclerosis, but the reasons for these elevated levels remain unknown. One possibility to explain them is variation in the sequences that control $I G F-1$ gene expression. The goal of this study was to determine the effect of molecular variants of the IGF-1 P1 promoter on IGF-1 serum levels and to determine the impact of IGF-1 levels on the severity of coronary atherosclerosis. Methods: Blood samples were collected from 101 consecutive patients undergoing routine angiography. Genomic DNA was isolated from the nucleated cells of the blood plasma as described (2). Based on the presence of conformational differences in the DNA strand and on the absence of single nucleotide polymorphisms, the DNA from 38 patients was further analyzed by the "allelic ladder" method to determine the number of repeated GC dinucleotides in the P1 promoter of the IGF-1 gene. In addition, we analyzed serum growth hormone levels in order to examine the effect on systemic IGF-1 synthesis. Results: Conformational differences in the P1
\end{abstract}

P. Burchardt $(\bowtie)$

Division of Cardiology-Intensive Therapy, Department of Internal Medicine, Poznan University of Medical Sciences, ul. Przybyszewskiego 49, 60-355 Poznan, Poland e-mail: pab2@tlen.pl

W. Nowak · A. Gozdzicka-Jozefiak Department of Biology, Adam Mickiewicz University, Poznan, Poland

J. Zurawski

Department of Biology and Environmental Sciences, Poznan

University of Medical Sciences, Poznan, Poland

T. Siminiak

Poznan University of Medical Sciences, Poznan, Poland promoter of the $I G F-1$ gene were observed in 38 out of the 101 patients. Several genotypes, depending on the number of GC repeats, were observed (11/19,17/19,18/19,18/21,19/ $19,19 / 20,19 / 21)$. Interestingly, a family history of coronary artery disease was seen less often among individuals heterozygous for the GC repeats. A lower IGF-1 levels were seen in non-variant carriers (homozygous genotypes for 19 or 21 repeats of GC, or heterozygous genotype 19/21) when compared to the variant group (other heterozygous genotypes then $19 / 21)(181.6 \pm 47.9 \mathrm{ng} / \mathrm{mL}$ vs. $227.7 \pm$ 73.7, $p=0.026$ ). A correlation between IGF-1, IGFbinding protein number 3 , and growth hormone levels $(p=n s)$ was not observed, and there were no significant differences in the growth hormone levels in the studied group of patients $(p=\mathrm{ns})$.

Keywords IGF-1 - Promoter P1 polymorphism of IGF-1 gene $\cdot$ Growth hormones $\cdot$ CAD $\cdot$ Allele bp192

$\begin{array}{ll}\text { Abbreviations } \\ \text { ACS } & \text { Acute coronary syndrome } \\ \text { Apo A1 } & \text { Apoprotein A1 } \\ \text { Apo B100 } & \text { Apoprotein B-100 } \\ \text { BMI } & \text { Body mass index } \\ \text { CAD } & \text { Coronary artery disease } \\ \text { FAM-6 } & \text { Carboxyfluorescein } \\ \text { GH } & \text { Growth hormone } \\ \text { HDL, LDL } & \text { High/low density lipoproteins } \\ \text { IGF } & \text { Insulin like growth factor } \\ \text { Lp(a) } & \text { Lipoprotein a } \\ \text { MI } & \text { Myocardial infarction } \\ \text { Nt } & \text { Nucleotide } \\ \text { NYHA } & \text { New York Heart Association- the clinical } \\ & \text { classification of advancing of heart failure }\end{array}$


PPPA Pregnancy plasma protein A

PAGE Polyacrylamide gel

QCA Quantitative coronary angiography

TC Total cholesterol

\section{Introduction}

IGF-1 affects the homeostasis of the vessel wall [1]. IGF-1 deficiency may precipitate the apoptosis of smooth muscle cells migrating to the endothelial layer, as well as the cells found in the media of the vessel. This probably contributes to the destabilization of artherosclerotic plaque [2]. IGF-1 prevents the dilation of heart muscle by activating cardiac progenitor cells and inhibiting apoptosis of cardiomyocytes and VSMC hypertrophy [3]. The concentration of IGF-1 also increases in cases of acute ischaemia and is correlated with the level of troponin [4]. This system is known as PAAP (pregnancy plasma protein A)/IGF-1, and is observed in early response to cardiac muscle ischaemia [4].

The role of insulin-like growth factor 1 (IGF-1) in the progression of coronary atherosclerosis is unclear $[1,3,5]$. Further, little is known about the connection between tissue protein levels of IGF-1, IGF-binding proteins (IGFBPs), and their concentrations in the serum. In one of the few studies addressing this subject [3], it was reported that low systemic levels of IGF-1 and high systemic levels of IGF binding protein-1 number 3 (IGFBP3) were a direct risk factor for coronary artery disease, which has been further confirmed by the results of some prospective clinical studies [4]. However, in a preliminary study, we found significantly higher levels of plasma IGF-1 in patients with advanced coronary atherosclerosis (unpublished results). These conflicting results leave the role of IGF-1 levels in coronary atherosclerosis an unresolved question.

The possible impact of structural gene variation on systemic levels of IGF-1 remains unknown. Two studies suggest a relation between allele $192 \mathrm{nt}$ ( $38 \mathrm{nt}$ or repeat 19 in our study) and IGF-1 levels. This allele displays 19 GC dinucleotides repeats in the IGF-1 P1 promoter sequence in the region between $-1,115$ and $-784 \mathrm{nt}$.

Our preliminary data has suggested that allelic diversity in that region has a possible impact on advanced stages of coronary artery disease [6]. However, this data was based on an analysis of the promoter P1 region by SSCP and TAG-polymerase sequencing techniques and did not allow for an accurate evaluation of the length of the analysed P1 promoter region. The aim of this project was to determine the influence of the GC repeats in the region between $-1,115$ and $-784 \mathrm{nt}$ on plasma IGF-1 levels and the progression of coronary atherosclerosis in patients undergoing routine coronary angiography.

\section{Methods}

\subsection{Patient Selection}

Patients were selected for the study if a coronary angiography had been performed, as determined on the basis of an exercise test and the presence of clinical symptoms of coronary heart disease. The group of patients included 44 women and 57 men. Patients were excluded if they displayed acute coronary syndrome, myocardial infarction during the preceding 3 months, acute congestive heart failure (NYHA III/IV), acute or chronic hematopoietic disease, cancer, acromegaly, or inflammation originating from bacterial, viral, or fungal infections. The study protocol was approved by the local ethics committee.

\subsection{Detection of Polymorphisms by SSCP}

Blood samples were collected from 101 consecutive patients, and DNA was isolated from the leukocytes with DNA isolation kits. SSCP analysis was performed to detect polymorphisms through differences in the migration of the products on SDS-PAGE gels, and the results were verified by the Sanger sequencing method, using Big Dye Terminator kit v3.1 as described [6].

\subsection{Allelic Ladder Technique}

If the migration of DNA strands were altered in polyacrylamide electrophoresis (PAGE)-SSCP gels and no mutations were evidenced by sequencing analysis, the material was analysed by the DNA allelic ladder technique to determine the exact number of GC dinucleotides repeats in the region $-1,115$ to -784 in the $\mathrm{P} 1$ promoter of the $I G F-1$ gene. Genomic DNA (20 ng) was amplified in a $30 \mu \mathrm{L}$ reaction mix containing 7.5 pmol forward primer (5'-ACTTTCTTATCTACTGCTTCACAA- $\left.3^{\prime}\right), \quad 7.5$ pmol reverse primer ( $5^{\prime}$-ACCACTCTGGGAGAAGGGTA- $\left.3^{\prime}\right)$, $0.1 \mathrm{mM}$ d-NTP, $1.5 \mathrm{mM} \mathrm{MgCl} 2,1 \times$ PCR buffer, and 1.2 U HiFi DNA polymerase (Novazym, Poland). The reactions were performed in a 2,720 Thermal Cycler (Applied Biosystems, USA) $\left(94{ }^{\circ} \mathrm{C}\right.$ for $4 \mathrm{~min} ; 30$ cycles each at $94{ }^{\circ} \mathrm{C}$ for $5 \mathrm{~s} ; 55^{\circ} \mathrm{C}$ for $10 \mathrm{~s}$, and at $60{ }^{\circ} \mathrm{C}$ for $30 \mathrm{~s}$; and a final extension at $65^{\circ} \mathrm{C} 30 \mathrm{~min}$.) The reaction products were gel purified using the kit QIAquick Gel Extraction Kit (Qiagen, Japan) and subcloned into EasyVector pGEM-T (Promega, USA). Recombinant plasmids were isolated and sequenced to determine the number of repeated GC dinucleotides. Sequencing reactions were carried out using the BigDye Terminator 3.1 kit (Applied Biosystems, USA) according to manufacturer's guidelines. The sequences were read automatically with ABI $3,130 \times 1$. Selected plasmids were used as matrices for the separate 
amplification of amplicons labeled with FAM. PCR was carried out in $15 \mu \mathrm{l}$ reactions with approximately $5 \mathrm{ng}$ plasmid DNA, 2.25 pmol forward primer (5'-AAGAAAA CACACTCTGGCAC - $3^{\prime}$ ) labeled with FAM, 2.25 pmol reverse primer (5'-ACCACTCTGGGAGAAGGGTA- $\left.3^{\prime}\right)$, $0.1 \mathrm{~m} \mathrm{mM}$ d-NTP, $1.5 \mathrm{mM} \mathrm{MgCl}_{2}$ buffer, and $0.6 \mathrm{U}$ $1 \times$ PCR HiFi DNA polymerase (Novazym, Poland). The reaction was performed in a 2,720 thermal cycler (Applied Biosystems, USA) $\left(94{ }^{\circ} \mathrm{C}\right.$ for $4 \mathrm{~min} ; 25$ cycles each of $94{ }^{\circ} \mathrm{C}$ for $5 \mathrm{~s}$ and $60{ }^{\circ} \mathrm{C}$ for $30 \mathrm{~s}$; and a final extension at $65{ }^{\circ} \mathrm{C}$ for $30 \mathrm{~min}$.) PCR products were collected in the form of allelic ladders and analysed in an apparatus for automated sequencing ABI 3,130×1 with internal standard size GS600LIZ (Applied Biosystems, USA).

\subsection{Determination of IGFPB3, IGF-1, and GH Levels}

The serum concentrations of IGFBP3 and IGF-1 were estimated by radioimmunoisotopic and radioisotopic assays using reagents from BioSource (Nivelles, Belgium) [6]. GH serum levels were estimated using commercially available ELISA kits (DRG International, USA).

\section{Results}

Test groups were homogenous in terms of basic clinical parameters (Tables 1, 2, 3). SSCP analysis detected polymorphisms in the region between $-1,115$ and -784 in the P1 promoter of the $I G F-1$ gene in 38 of the 101 patients. Each SSCP was established by differences in the migrational speed of the DNA strands in PAGE and by the absence of any mutation as shown by sequencing analysis [6]. Among these 38 patients, a large number of genotypes were present based on the number of GC repeats (Table 4). Twenty-five patients were heterozygotes and 13 were homozygotes. The remaining 63 patients were previously found to be homozygotes based on SSCP and sequencing analysis [6]. There were no statistically significant differences in the IGF-1 plasma levels between the homozygous (due to most frequent genotype $19 / 19, N=76$ ) and heterozygous group (genotypes 11/19, 17/19, 18/19, 18/21,19/ $20,19 / 21, N=25$ ). However, heterozygotes notably had a less frequent family history of coronary artery disease $(\mathrm{CAD} ; p=0.00015)$. There were no significant differences between groups with regard to severity of atherosclerosis or past heart attacks.

Based on a protocol established by Yazdanapah [7], different genotypes were assigned to two groups: Group 1 consisted of non- variant carriers (homozygotes due to 19 GC cassette replicates or homozygotes to 21 cassettes GC replicates or heterozygous 19 -rep/21-rep i.e. $38 \mathrm{nt} / 42 \mathrm{nt}$. Group 2 consisted of variant carriers (heterozygous genotypes other then genotype 19/21). In group 2, higher plasma levels of IGF-1 were observed relative to those in group $1(227.7 \pm 73.7 \mathrm{ng} / \mathrm{mL}$ vs. $181.6 \pm 47.9 \mathrm{ng} / \mathrm{mL}$, $p=0.026)$. Unfortunately, the low number of subjects within each group prevented a statistical evaluation in regards to the severity of atherosclerosis, family history of $\mathrm{CAD}$, or past myocardial infarction. A correlation between IGF-1, IGFBP3 and growth hormone $(p=n s)$ was not observed, nor were there any significant differences in growth hormone levels $(p=\mathrm{ns})$.

\section{Discussion}

Grant et al. [8] was the first publication to report lack of IGF-1 expression in normal coronary arteries and its overexpresion in post-atherectomy specimens. Jansen [9] associated high serum IGF-1 levels with decreased prevalence of CAD.

Despite these observations, it was found that the extent of myocardial infarction correlates with elevated systemic concentrations of IGF-1 and GH [10] within a few days after an acute coronary syndrome, especially among people who die a few months after myocardial infarction [11, 12]. One interpretation is that these increased levels may reflect the anti-apoptotic properties of IGF-1 and GH and hence prevent the adverse post-infarction remodelling of the left ventricle [13].

Because of how little is known about the process, it is still difficult to draw conclusions about the mechanism that might account for the significantly higher levels of IGF-1 in patients with advanced coronary atherosclerosis (preliminary data). However, several different hypotheses can be advanced. First, elevated levels of GH could account for the increased levels of IGF-1. However, this explanation is unlikely because IGF-1 levels did not correlate with the level of GH. Indeed, all study participants displayed normal GH levels $(<7 \mathrm{ng} / \mathrm{mL})$. Second, the elevated plasma/ serum IGF-1 levels could be the result of increased expression of proteases releasing IGF-1 from the ternary complex (IGF-1 + IGFBP3 + acid-labile protein), which is also secreted in response to ischeamia [3]. Third, an increase in hepatic $I G F-1$ gene expression under the influence of inflammatory mediators or variability in the regulatory sequences responsible for its expression.

Before testing any of these hypotheses, we first wanted to determine the impact of a single genetic variant, which can influence IGF-1 synthesis and the prognosis for patients with a family history of CAD. While the IGF-1 protein-coding sequence is highly conserved, the promoter is highly variable. One of its molecular variants, described in a large-population Rotterdam Study, contains a different number of GC nucleotide repetitions in the region between 
Table 1 Characteristics of group with conformational differences in region between 1,115 and -784 in the P1 promoter of the $I G F-1$ gene divided into variant carriers and non variant carriers according to the GC repeats estimation

ApoA1 apoprotein A1, ApoB100 apoprotein B-100, $B M I$ body mass index, $H D L, L D L$

lipoproteins, $I G F$ insulin like growth factor, $\operatorname{Lp}(a)$ lipoprotein a, $T C$ total cholesterol, IGFBP3 IGF binding protein number 3

\begin{tabular}{llll}
\hline Parameters & Variant carriers & Non variant carriers & $\begin{array}{l}\text { All subjects with observed } \\
\text { conformational differences } \\
\text { in region between }-1,115 \\
\text { and }-784 \text { in the P1 promoter } \\
\text { of the } I G F-1 \text { gene } \\
\text { Mean } \pm \text { SD }(N=38)\end{array}$ \\
\hline Weight $(\mathrm{kg})$ & $85.8 \pm 15$ & $78.8 \pm 14.0$ & $81 \pm 14.5$ \\
Height $(\mathrm{cm})$ & $170.1 \pm 7.8$ & $163.9 \pm 9.4$ & $165.9 \pm 9.3$ \\
BMI $\left(\mathrm{kg} / \mathrm{m}^{2}\right)$ & $29.8 \pm 5.9$ & $29.1 \pm 3.8$ & $29.3 \pm 4.5$ \\
TC $(\mathrm{mg} / \mathrm{dL})$ & $198.2 \pm 53.2$ & $202.2 \pm 56.6$ & $201 \pm 54.8$ \\
HDL $(\mathrm{mg} / \mathrm{dL})$ & $44.8 \pm 11.2$ & $52.0 \pm 13.3$ & $49.7 \pm 13.0$ \\
LDL $(\mathrm{mg} / \mathrm{dL})$ & $124.8 \pm 43.8$ & $122.6 \pm 50.1$ & $123.3 \pm 47.6$ \\
Lp(a) $(\mathrm{g} / \mathrm{L})$ & $0.12 \pm 0.14$ & $0.19 \pm 0.24$ & $0.17 \pm 0.22$ \\
Apo B-100 $[\mathrm{g} / \mathrm{L}]$ & $1.02 \pm 0.31$ & $1.1 \pm 0.32$ & $1.04 \pm 0.31$ \\
Apo A1(g/L) & $1.46 \pm 0.2$ & $1.57 \pm 0.23$ & $1.5 \pm 0.2$ \\
IGF/BMI & $8.1 \pm 3.6$ & $6.3 \pm 1.9$ & $6.9 \pm 2.66$ \\
IGF-1 $(\mathrm{ng} / \mathrm{mL})$ & $227.6 \pm 73.7$ & $181.6 \pm 47.9$ & $196 \pm 60.3$ \\
IGFBP3 (ng/mL) & $2,092.6 \pm 721.3$ & $2,081.7 \pm 504.5$ & $2,085.2 \pm 653.7$ \\
Diabetes mellitus $(\%)$ & 13.16 & 23.68 & 36.84 \\
Smoking cigaretes $(\%)$ & 13.16 & 7.89 & 21.05 \\
Hypertension $(\%)$ & 23.68 & 50 & 73.68 \\
\hline
\end{tabular}

Table 2 Basic parameters in all consecutive patients scheduled for routine coronary-angiography

\begin{tabular}{llll}
\hline Parameters & $\begin{array}{l}\text { Mean value } \pm \text { SD } \\
\text { in female group }(N=44)\end{array}$ & $\begin{array}{l}\text { Mean value } \pm \text { SD } \\
\text { in male group }(N=57)\end{array}$ & $\begin{array}{l}\text { Mean value } \pm \text { SD in } \\
\text { all examined patients } \\
(N=101)\end{array}$ \\
\hline Weight $(\mathrm{kg})$ & $72.7 \pm 14$ & $82.8 \pm 13.83$ & $78.47 \pm 14.7$ \\
Height $(\mathrm{cm})$ & $159.2 \pm 6.92$ & $171.57 \pm 6.67$ & $166.3 \pm 9.12$ \\
BMI $\left(\mathrm{kg} / \mathrm{m}^{2}\right)$ & $28.57 \pm 4.52$ & $28.07 \pm 4.05$ & $28.28 \pm 4.24$ \\
TC $(\mathrm{mg} / \mathrm{mL})$ & $198.7 \pm 55.14$ & $191.46 \pm 47.88$ & $194.6 \pm 50.97$ \\
HDL $(\mathrm{mg} / \mathrm{mL})$ & $53.31 \pm 16.32$ & $45.21 \pm 13.58$ & $48.68 \pm 15.28$ \\
LDL $(\mathrm{mg} / \mathrm{mL})$ & $116.59 \pm 48.3$ & $119.21 \pm 41.65$ & $118.1 \pm 44.37$ \\
TG $(\mathrm{mg} / \mathrm{mL})$ & $144.26 \pm 59.12$ & $144.21 \pm 79.99$ & $144.2 \pm 71.46$ \\
Lp $(\mathrm{a})(\mathrm{g} / \mathrm{L})$ & $0.179 \pm 0.233$ & $0.14 \pm 0.18$ & $0.162 \pm 0.2$ \\
Apo B-100 $(\mathrm{g} / \mathrm{L})$ & $1.006 \pm 0.376$ & $1.01 \pm 0.29$ & $1.008 \pm 0.33$ \\
Apo AI $(\mathrm{g} / \mathrm{L})$ & $1.621 \pm 0.261$ & $1.46 \pm 0.22$ & $1.532 \pm 0.25$ \\
IGF-1/BMI & $6.571 \pm 1.912$ & $7.57 \pm 2.57$ & $7.147 \pm 2.35$ \\
IGF-1 $(\mathrm{ng} / \mathrm{mL})$ & $183.71 \pm 47.25$ & $207.91 \pm 61.88$ & $197.5 \pm 57.1$ \\
IGFBP3 $(\mathrm{ng} / \mathrm{mL})$ & $2,210.9 \pm 675.9$ & $2,021.6 \pm 623.13$ & $2,102.7 \pm 649.74$ \\
Hypertension $(\%)$ & 78.6 & 62 & 69 \\
Diabetes mellitus $(\%)$ & 28.6 & 21 & 24.5 \\
Smoking cigaretes $(\%)$ & 11.9 & 30 & 22.4 \\
\hline ApoA1 & & &
\end{tabular}

ApoA1 apoprotein A1, Apo B100 apoprotein B-100, BMI body mass index, HDL,LDL lipoproteins, IGF insulin like growth factor, $L p(a)$ lipoprotein a, $T C$ total cholesterol, $T G$ triglicerydesl, IGFBP3 IGF binding protein number 3

$-1,115$ and -784 nt. Our preliminary data [6] showed a lower incidence of advanced coronary atherosclerosis in patients with the SSCP in this region of the P1 promoter. Further molecular analysis was used to determine the exact number of GC repeats in 38 cases, and the findings were confirmed only in 25 patients. There were no significant differences in IGF-1 levels, in the degree of coronary atherosclerosis, or in the MI history between patients who were homozygous and those who were heterozygous for the GC repeats. Only the rare occurrence of the familial CAD load in the group of heterozygotes may partially confirm our preliminary findings [6]. 
Table 3 Characteristics of groups divided into most frequent genotypes due to the GC repeats estimation

\begin{tabular}{lll}
\hline Parameters & $\begin{array}{l}\text { Heterozygous genotypes } \\
(11 / 19,17 / 19,18 / 19,19 / \\
20,19 / 21, \text { Mean } \pm \mathrm{SD}\end{array}$ & $\begin{array}{l}\text { Homozygous } \\
\text { genotype 19/19 } \\
\text { (most frequent } \\
\text { in analysis) } \\
\text { Mean } \pm \text { SD N74 }\end{array}$ \\
\hline Weight $(\mathrm{kg})$ & $80.01 \pm 15$ & $77.8 \pm 14.6$ \\
Height $(\mathrm{cm})$ & $166.6 \pm 9.3$ & $164.9 \pm 9.05$ \\
BMI $\left(\mathrm{kg} / \mathrm{m}^{2}\right)$ & $29.4 \pm 4.9$ & $27.9 \pm 3.9$ \\
TC $(\mathrm{mg} / \mathrm{dL})$ & $188.1 \pm 55.05$ & $197.27 \pm 49.2$ \\
HDL $(\mathrm{mg} / \mathrm{dL})$ & $48.25 \pm 13.7$ & $48.25 \pm 13.7$ \\
LDL $(\mathrm{mg} / \mathrm{dL})$ & $110.7 \pm 45.5$ & $121.1 \pm 43.4$ \\
Lp(a) $(\mathrm{g} / \mathrm{L})$ & $0.14 \pm 0.15$ & $0.16 \pm 0.21$ \\
Apo B-100 $(\mathrm{g} / \mathrm{L})$ & $0.99 \pm 0.26$ & $1.01 \pm 0.34$ \\
Apo A1 $(\mathrm{g} / \mathrm{L})$ & $1.5 \pm 0.25$ & $1.5 \pm 0.25$ \\
IGF/BMI & $7.0 \pm 3.1$ & $7.2 \pm 2.05$ \\
IGF-1 $(\mathrm{ng} / \mathrm{mL})$ & $195.3 \pm 68.9$ & $199.2 \pm 55$ \\
IGFBP3 (ng/mL) & $1,987.04 \pm 676.9$ & $2,151.8 \pm 641.83$ \\
Diabetes mellitus $(\%)$ & 41.6 & 18.9 \\
Smoking cigaretes & 29.17 & 21.05 \\
(\%) & & 67.11 \\
Hypertension $(\%)$ & 75 & \\
\hline ApoA1 apoprotin A1 & &
\end{tabular}

ApoA1 apoprotein A1, Apo B100 apoprotein B-100, BMI body mass index, $H D L, L D L$ lipoproteins, $I G F$ insulin like growth factor, $L p(a)$ lipoprotein a, TC total cholesterol, IGFBP3 IGF binding protein number 3

Table 4 Frequency of genotypes in studied population

\begin{tabular}{lll}
\hline $\begin{array}{l}\text { Genotypes according } \\
\text { to the number of } \\
\text { repeated GC dinucleotides } \\
\text { between }-1,115 \text { and } \\
\text {-784 nt in p1 promoter } \\
\text { of IGF-1 gene }\end{array}$ & $\begin{array}{l}\text { Frequency of } \\
\text { genotypes in } \\
\text { examined } \\
\text { population } N\end{array}$ & $\begin{array}{l}\text { Frequency of } \\
\text { genotypes in } \\
\text { examined } \\
\text { population } N \%\end{array}$ \\
\hline $\begin{array}{l}\text { Genotype } 19 \backslash 21(19 / 21 \\
\text { repeats of GC) }\end{array}$ & 13 & 12.87 \\
Genotype 19\19 & 76 & 75.25 \\
Genotype 18\19 & 3 & 2.97 \\
Genotype 19\20 & 6 & 5.94 \\
Genotype $11 \backslash 19$ & 1 & 0.99 \\
Genotype $17 \backslash 19$ & 1 & 0.99 \\
Genotype $18 \backslash 21$ & 1 & 0.99
\end{tabular}

${ }^{\text {a }} 63$ cases due to observed SSCP, 13 cases confirmed by allelic ladder

In the current study, due to large diversity of observed genotypes, we additionaly created two groups (following Yazdanapah). First group contains "non variant" subjects and second one, individuals carrying "variant". Although the variant carriers showed significantly higher levels of IGF-1(in opposition to Yazdanapah), the number of cases of previous myocardial infarction and the severity of coronary atherosclerosis (estimated by the number of significant narrowing lesions in coronary arteries) were similar between both groups. Therefore, we can confirm previous two literature observations that polimorphism associated with different number of GC nucleotide repetitions in the region between $-1,115$ and -784 nt has an impact on the systemic IGF-1 pool, yet it remains an unresolved issue whether the frequency of its various genotypes in the general population will indeed have an influence on and correlate with the severity of ischaemic heart disease. In view of that, it seems that our conclusions do not account for the phenomenon of statistically significant elevated IGF-1 levels, nor do they explain the role of IGF-1 in patients with an advanced form of stable ischaemic heart disease, as it is difficult to imagine that the local synthesis of IGF-I in the coronary vessel wall could increase systemic levels of this protein to such high levels. One can only speculate that the increased pool of systemic IGF-1, caused by an unknown mechanism, protects against the adverse consequences of plaque rupture.

The indisputable limitations of our study were the small number of participants and the uncertainty arising from the angiographic examination itself (i.e. no possibility of verifying the processes taking place in the coronary vessel wall). In addition, the technique for assessing the number of GC repeats was employed only in the 38 cases where the SSCP was observed. Thus, only 13 homozygotes with respect to the $38 \mathrm{nt}$ allele were confirmed by the allelic ladder technique. The remaining 63 other patients were also homozygous, but the utilised SSCP technique could not identify the exact number of GC repetitions. Therefore, we assumed that they were carriers of allele $38 / 38 \mathrm{nt}$. This assumption is founded on two facts. First, it was the only homozygous genotype found in the studied population, which was additionally confirmed in all 63 cases by the DNA strands in a polyacrylamide gel migrating at the same rate. Secondly, the results of sequencing the P1 promoter fragment showed no mutational variations, as described in [6]. Therefore, it appears that the applied procedure was sufficient to exclude polymorphisms, and only the discrepancy between the results of SSCP and sequencing required further molecular verification, which has been done.

\section{Conclusions}

The presence of variants in the study population is associated with significantly higher levels of systemic IGF-1. Among individuals heterozygous for GC repeats, the family CAD was less frequent. The verification of observations concerning the relationship of IGF-1 with the advanced atherosclerotic process is likely to be possible 
only after the exclusion of molecular variation within the entire P1 promoter gene and the receptor gene for IGF-1.

Acknowledgment Poster presentation based on the results of the study were presented at ESC 2009. Special thanks for Simon Nowak for contribution in text edits

Open Access This article is distributed under the terms of the Creative Commons Attribution Noncommercial License which permits any noncommercial use, distribution, and reproduction in any medium, provided the original author(s) and source are credited.

\section{References}

1. Burchardt P, Gozdzicka-Jozefiak A, Siminiak T (2006) Kard Pol 64:1297-1302

2. Frystyk J, Ledet T, Moller N, Flyvbjerg A, Orskov H (2002) Circulation 106:893-895
3. Delafontaine P, Song Y-H, Li Y (2004) Arterioscler Thromb Vasc Biol 24:435-444

4. Dimmeler S, Zeiher AM (2003) Circulation 107:3118-3120

5. Shamblott MJ, Chen TT (1992) Proc Natl Acad Sci USA 89(19):8913-8917

6. Burchardt P, Gozdzicka-Jozefiak A, Nowak W, Link R, Grotowski T, Wisniecka A, Siminiak T (2009) Heart Vessels 24(4): 254-259

7. Yazdanpanah M, Rietveld I, Janssen JA, Njajou OT, Hofman A, Stijnen T, Pols HA, Lamberts SW, Witteman JC, van Duijn CM (2006) Am J Cardiol 97:1274-1276

8. Grant MB, Wargovich TJ, Ellis EA, Tarnuzzer R, Caballero S, Estes K, Rossig M, Spoerri PE, Pepine C (1996) Regul Pept 67:137-144

9. Janssen JA, Stolk RP, Pols HA, Grobbee DE, Lamberts SW (1998) Arterioscler Thromb Vasc Biol 18:277-282

10. Conti E, Andreotti F, Sciahbasi A, Riccardi P, Marra G, Menini E, Ghirlanda G, Maseri A (2001) J Am Coll Cardiol 38:26-32

11. Delafontaine P (1995) Cardiovasc Res 30:825-834

12. Ledet T, Heickendorff L (1985) Diabetologia 28:922-927

13. Friberg L, Werner S, Eggertsen G, Ahnve S (2000) Eur Heart J $21: 1547-1554$ 